\title{
Effect of automatic cluster removers on milking efficiency and teat condition of Manchega ewes
}

\author{
J. Bueso-Ródenas, ${ }^{*}$ G. Romero, ${ }^{*}$ R. Arias, † A. M. Rodríguez, $\ddagger$ and J. R. Díaz ${ }^{* 1}$ \\ *Departamento Tecnología Agroalimentaria, Universidad Miguel Hernández (UMH), 03312 Orihuela, Spain \\ †Centro Regional de Selección y Reproducción Animal (CERSYRA), Consejería de Agricultura y Medio Ambiente de Castilla-La Mancha, \\ Valdepeñas, Spain 13300 \\ ‡Asociación Nacional de Criadores de Ganado Ovino Selecto de Raza Manchega (AGRAMA), Instalaciones del ITAP, 02006 Albacete, Spain
}

\begin{abstract}
Milking operations represent more than $50 \%$ of the work on a dairy ewe farm. The implementation of automatic cluster removers (ACR) is gaining popularity, as it allows the operator to avoid manual cluster detachments, simplifying the milking routines. The aim of this study was to discover the effect on the milking of Manchega ewes over an entire lactation period by using this type of devices, set up with 2 different combinations of milk flow threshold (MF) and delay time (DT) and comparing them with the traditional method using manual cluster removal. During a 15-d pre-experimental period, the animals were milked without ACR and sampling was performed to select 108 ewes and distribute them into 3 groups of similar characteristics according to their parity, milk yield, milking duration, and mammary gland sanitary status. Later, each group was milked for a duration of 4 mo in 3 different conditions: 1 with manual cluster removal, the second setting the ACR at MF $150 \mathrm{~g} / \mathrm{min}$ and DT $20 \mathrm{~s}$, and the third setting the ACR at MF $200 \mathrm{~g} / \mathrm{min}$ and DT $10 \mathrm{~s}$. Samplings of milking fraction, milking duration, milk composition, mammary gland sanitary status, teat-end status, and vacuum level in the short milk tubes during milking were performed. The use of ACR limited the vacuum drops in the short milk tubes and the edema in the teat end after milking, although no reduction in the number of new cases of mastitis was observed and the milk composition did not change. Moreover, it was noted that the use of ACR set with MF $150 \mathrm{~g} / \mathrm{min}$ and DT $20 \mathrm{~s}$ was more efficient than the manual cluster removal, as it obtained a similar amount of extracted milk but took less time. Conversely, the use of ACR set with MF $200 \mathrm{~g} / \mathrm{min}$ and DT $10 \mathrm{~s}$ involved a higher reduction in individual milking duration and
\end{abstract}

Received November 12, 2014.

Accepted March 4, 2015.

${ }^{1}$ Corresponding author: jr.diaz@umh.es the milking duration of groups of animals but reduced milk extracted.

Key words: automatic cluster remover, Manchega ewe, milking fractioning, milking duration

\section{INTRODUCTION}

Milking operations constitute more than $50 \%$ of the work on a dairy ewe farm (Olechnowicz, 2012). With the aim of reducing the time spent on these tasks, several studies on the simplification of milking routines have been carried out (Labussière, 1988; Molina et al., 1989; Knight and Gosling, 1995). Complex routines including double cluster attachments, intense stimulation of the udder, and hand stripping were substituted by simpler routines, such as cluster attachment, brief machine stripping, and cluster detachment. Moreover, the elimination of the machine-stripping phase has been proposed in those particular breeds selected for their milkability. Thus, in studies conducted in Sarda and Lacaune breeds, elimination of the machine stripping in animals with a large milk storage capacity reduced the milking duration, whereas milk yield was not affected (Labussière, 1988). In Poll Dorset breed ewes, no significant differences in milk yield were found among animals that were machine stripped and animals milked following routines that only included cluster attachment and cluster detachment (Knight and Gosling, 1995). In Manchega breed ewes, according Molina et al. (1989), the elimination of one or both daily machine strippings in ewes with bimodal ( 2 peaks) milk emission flow only represented losses from 3 to $9 \%$, respectively; those authors suggested that such animals should not be machine stripped. McKusick et al. (2003) added that the elimination of machine stripping in East Friesian ewes reduced the milk yield by $14 \%$, but allowed a reduction in working times. Thus, in farms of these breeds, if these simple routines are applied, the implementation of automatic cluster removers (ACR) could be an interesting choice. The use of ACR adjusted with optimal levels of their operating parameters [switch point or 
milk flow threshold (MF) and delay time from which MF is reached (DT)] has been very suitable in dairy cows to reduce the milking duration while maintaining the income from milk quantity and quality (Rasmussen, 1993; Reid and Stewart, 1997; Magliaro and Kensinger, 2005; Edwards et al., 2013).

In milking parlors for small ruminants where ACR are present, usually only automatic vacuum cutting devices (AVCD; a component of ACR that interrupts the vacuum but does not remove the milking unit) are implemented. In dairy goats, the use of AVCD reduces the need for staff during the milking procedures, which is related to better profitability of the farm (Tangorra et al., 2007). According to Tangorra et al. (2010), the use of these devices reduces the risk of over-milking, which improves the sanitary status of the mammary gland (Peris et al., 2003). In a previous experiment carried out by our research group (Bueso-Ródenas et al., 2014a), it was concluded that the optimal settings for the AVCD in milking Murciano-Granadina goats was the combination of MF between 100 and $150 \mathrm{~g} / \mathrm{min}$ and DT $10 \mathrm{~s}$. The use of higher MF required more frequent second cluster attachments and, consequently, significantly increased milking duration. Moreover, when DT was higher than $10 \mathrm{~s}$ in a concrete MF, milking duration and mean vacuum drop in the short milk tube increased but machine milk fraction was not improved. In a later study developed on Murciano-Granadina goats [J. Bueso-Ródenas, G. Romero, M. P. Gascó (Universidad Miguel Hernández), and J. R. Diaz, unpublished data], the use of AVCD set at MF 100 or $150 \mathrm{~g} / \mathrm{min}$ and DT $10 \mathrm{~s}$ did not affect the results of milking fractioning and individual milking duration of the animals when compared with manual cluster removal. Although no differences in the sanitary status of the mammary gland and milk composition were observed, the milking with manual cluster removal caused a higher teat-end edema and increased the mean vacuum drops in the short milk tube. It was concluded that the implementation of AVCD and its use with the given MF and DT was as effective as milking with cluster removal performed by an experienced milker [J. Bueso-Ródenas, G. Romero, M. P. Gascó (Universidad Miguel Hernández), and J. R. Diaz, unpublished data].

Along similar lines, the implementation of AVCD in milking parlors for dairy ewes is an increasingly popular choice. In Manchega ewes, Bueso-Ródenas et al. (2014b) carried out a short-term study in 2 different AVCD with different MF and DT; the main conclusions were that, when AVCD were installed in a highline milking machine, the combination of MF $150 \mathrm{~g} /$ min and DT $20 \mathrm{~s}$ achieved the best milking fractioning values and the combination of MF $200 \mathrm{~g} / \mathrm{min}$ and DT $10 \mathrm{~s}$ achieved the smallest values for milking duration.
Conversely, regarding an AVCD installed in a low-line milking machine, the use of MF $100 \mathrm{~g} / \mathrm{min}$ did not improve the milking fractioning and the use of MF 250 $\mathrm{g} / \mathrm{min}$ did not reduce the milking duration. Thus, it was concluded that the optimal setting was the combination of MF and DT between $150 \mathrm{~g} / \mathrm{min}$ and $20 \mathrm{~s}$ and $200 \mathrm{~g} / \mathrm{min}$ and $10 \mathrm{~s}$, with a balance existing between both combinations between milk yield and milking duration. Moreover, in both experiments the milking routine was not affected by the AVCD settings and the vacuum drops were deeper when high MF and DT were employed.

In dairy ewes, a lack of studies exist that compare milking with this kind of device and milking with manual cluster removal. The aim of the present study was to assess the effect of the AVCD on the milking of Manchega ewes during 1 lactation in terms of milk yield and milking fractioning, milking duration (individual and per groups of animals), milk composition, mammary gland health status, vacuum level in the short milk tubes, and teat-end status, comparing the parameters that obtained the best results in the previous shortterm experiment (Bueso-Ródenas et al., 2014b: MF 150 combined with DT $20 \mathrm{~s}$ and $200 \mathrm{~g} / \mathrm{min}$ combined with DT $10 \mathrm{~s}$ ) with conventional milking (manual cluster removal).

\section{MATERIALS AND METHODS}

\section{Facilities and Animal Handling}

The experiments were performed at the facilities of the Manchega Ewe National Herd, located in Valdepeñas, Spain, managed by Asociación Nacional de Criadores de Ganado Ovino Selecto de Raza Manchega (National Manchega Ewe Breeders Association). The animals were fed twice a day with the same ration (mixture of cereal grains and alfalfa hay) and water was offered ad libitum. Milking was practiced twice a day, at 0800 and $1700 \mathrm{~h}$, as is routine on Manchega ewe farms. This farm has a DeLaval (Tumba, Sweden) high-line milking machine installed in a $2 \times 18 \times 18$ Casse type milking parlor. The milking machine was equipped with AVCD (DeLaval SG) placed in the collector and linked to an electronic milk meter (mm25, DeLaval). The milk meters were connected through a long milk tube $2.5-\mathrm{m}$ long to the teat cups (Almatic G50+, DeLaval). The pulsation parameters used were 180 pulses/min and a pulsation ratio of $50 \%$; the vacuum level was $40 \mathrm{kPa}$.

\section{Experimental Design}

Pre-Experimental period. A pre-experimental period of $15 \mathrm{~d}$ was implemented to select the animals to 
be included in the study and determine the initial conditions of these animals. A first sampling was done in a group of 150 ewes with similar parturition date $(4 \pm 1$ postpartum weeks) in which milking fractioning, milking duration, and mammary gland sanitary status were recorded. From the results, 108 ewes with milk yield higher than $0.85 \mathrm{~kg}$, milking duration less than $5 \mathrm{~min}$, and free of clinical mastitis were selected, including 10 animals suffering subclinical mastitis and 28 primiparous ewes. The selected animals were distributed into 3 groups of 36 animals according to parity, milk yield, milking duration, and mammary gland health status.

During the pre-experimental period, all the animals were milked without the use of AVCD and the milking units were removed manually, based on the judgment of an experienced milker, and machine stripping was carried out. In this period, after the selection of the animals included in the study, samplings were done. The samplings included (1) sanitary status of the mammary gland; (2) milking fractioning, milking duration, and milk composition; (3) teat-end status; and (4) milking duration of each row of animals (18 ewes). Samplings of the milk composition, sanitary status of the mammary gland, and teat-end status were performed in the morning milking and samplings of milking fractioning, milking duration, and milking duration of each row of animals were performed in both daily milkings $(0800$ and $1700 \mathrm{~h}$ ). Each group of variables (1, 2, 3, and 4) was recorded once a month on 4 different nonconsecutive days.

Experimental Period. The experimental period began at $5 \pm 1$ postpartum weeks and lasted 4 mo, during which each group of animals was milked according to the milking conditions that were randomly assigned at the beginning of this period. Three different treatments were tested; one of them was employed as a control (TC: conventional milking without AVCD) and the other 2 to assess 2 AVCD settings: MF $150 \mathrm{~g} /$ min and DT $20 \mathrm{~s}$ (T15020) and MF $200 \mathrm{~g} / \mathrm{min}$ and DT $10 \mathrm{~s}$ (T20010). Every month, 4 samplings were carried out, similar to what was performed in the pre-experimental period. Samplings were performed on 4 different nonconsecutive days. In addition, every month, vacuum level measurements within each of the groups were recorded. Similar to what was performed in the pre-experimental period, samplings of the milk composition, mammary gland sanitary status, and teatend status were performed in the morning milking and samplings of milking fractioning, milking duration, and milking duration of each row of animals were performed in both daily milkings.

The milking routine in TC included cluster attachment, machine milking, machine stripping, and manual cluster removal at the end of milking. Finally, teats were immersed in an iodine solution. In TC, the milker could act during the milking to reattach the cluster in the case of falloff or to perform the machine stripping. The milking routine followed in T15020 and T20010 was similar to TC, with the exception that the cluster removal was performed by AVCD activation. Machine stripping and double cluster attachments after AVCD activation were never performed in T15020 and T20010. Finally, in both of these treatments, AVCD were set to not interrupt the vacuum for a minimum milking duration of $50 \mathrm{~s}$.

\section{Analyzed Variables}

Sanitary Status of the Mammary Gland. The mammary gland sanitary status was evaluated through bacteriological analysis and SCC of each mammary gland using milk samples obtained before milking. For bacteriological analysis, foremilk was discarded, the teats were cleaned with $70 \%$ alcohol, and $5-\mathrm{mL}$ samples of milk from each gland were taken. For SCC analysis, $50-\mathrm{mL}$ samples of milk were taken manually from each gland before machine milking and azidiol was added to them. Samples were kept at $4^{\circ} \mathrm{C}$ for up to 4 $\mathrm{h}$ until bacteriological analysis. Bacteriological analysis was performed by seeding $20 \mu \mathrm{L}$ of milk in blood agar plates (5\% sheep blood, Biomerieux, Lyon, France). The plates were incubated aerobically at $37^{\circ} \mathrm{C}$ and examined at 24, 48, and $72 \mathrm{~h}$. Microbiological cultures showing 5 or more identical colonies were considered positive. The SCC $\left(\times 10^{3}\right.$ cells $\left./ \mathrm{mL}\right)$ was analyzed in the dairy interprofessional laboratory of Castilla-La Mancha (LILCAM, Castilla-La Mancha, Spain) by the fluoro-opto-electronic method (Fossomatic 5000, Foss, Hillerød, Denmark).

It was determined that a gland showed IMI when the bacteriological analysis was positive. When the bacteriological analysis was negative but the SCC exceeded 400,000 cells $/ \mathrm{mL}$, it was also considered subclinical mastitis (Leitner et al., 2001). Finally, animals were classified mastitis-free when both mammary glands had this condition.

Milking Efficiency (Milking Fraction and Milking Duration) and Milk Composition. Values of machine milk (MM; kg) and milking duration (s) from every milking during both the pre-experimental and experimental periods were registered by the electronic milk meter (mm25, DeLaval) and stored by the corresponding software (Alpro Windows, DeLaval). The MM and milking duration were, respectively, the amount of extracted milk and the time elapsed since cluster attachment to AVCD activation (in the case of 
T15020 and T20010) or to manual cluster removal (in the case of TC).

In addition, once a month sampling was performed to determine the amount of milk remaining in the udder after cluster removal [hand-stripped milk (HSM), $\mathrm{g}]$ and the composition of the milk. The milking routine during these sampling days included cluster attachment, MM (recording test day MM and test day milking duration), cluster removal through AVCD or milker (including machine stripping in the TC group) and hand stripping (recording HSM), and, finally, teats were immersed in an iodine solution. The HSM was weighed with $\mathrm{a} \pm 1 \mathrm{~g}$ precision digital scale (BC-200, Fagor, Mondragón, País Vasco, Spain). Total milk (kg) was the sum of MM and HSM of both daily milkings in these sampling days. The milking duration of a row (min) lasted from the cluster attachment of the animal that was milked by the first milking unit to the last cluster removal of the row. It was recorded by a digital timer (HS-70W, Casio, Tokyo, Japan). All the preceding variables were recorded at the morning milking and at the afternoon milking.

Milk composition included its content in fat, protein, and lactose, expressed in percent of wet matter. The MM25 devices were set to obtain $50 \mathrm{~mL}$ of milk from the milking of each animal. On the same day, these samples were analyzed in the dairy interprofessional laboratory of Castilla-La Mancha (LILCAM) by a MilkoScan device (Foss).

Teat-End Status. A portable ultrasound device (Agroscan AL, ECM, Noveko International Inc., Angoulême, France) was used. Ultrasound scans of the right teat of each animal were performed before and after milking with a linear probe at $5 \mathrm{MHz}$ frequency employing $8 \mathrm{~cm}$ depth, according to the methodology of Díaz et al. (2013). The sonographic images obtained were recorded and digitally scanned with the software Real DVD Studio Gold (NPG Technology, Torrejón de Ardoz, Madrid, Spain). Later, video editor software (Ulead Video Studio, Corel, Ottawa, Canada) was used to take a frame of the sagittal plane of the teat end at the level of the teat sphincter. Finally, another software (Ecopezón, Universidad Miguel Hernández de Elche, Elche, Spain) was used to measure the following variables: (a) teat wall thickness (TWT): 2 lines were traced along the middle axis of the 2 teat walls and at $1 \mathrm{~cm}$ a line was drawn perpendicular to it, measuring the width $(\mathrm{cm})$ of each wall (upper and lower) to obtain the mean value of both measurements; (b) teat thickness $(\mathbf{T T} ; \mathrm{cm})$ : distance between both sides of the teat in a section at the level of the inner of the teat canal; (c) teat wall area (TWA; $\mathrm{cm}^{2}$ ): area covering both walls (upper and lower) to a distance of $1 \mathrm{~cm}$ from the teat end, including the teat end area; (d) teat end area (TEWA; $\left.\mathrm{cm}^{2}\right)$ : area from the inner to the outer end of the teat canal; (e) teat canal length $(\mathbf{T C L} ; \mathrm{cm})$ : distance from the inside to the outside of the teat canal. From the values recorded in the scans before the cluster attachment and after their removal, the percentage increase of each variable was computed according to the following mathematical formula:

$$
\begin{gathered}
\text { Increase } \%=[(\text { value after milking }- \text { value before } \\
\text { milking }) / \text { value before milking })] \times 100,
\end{gathered}
$$

The new variables obtained were increase of teat wall thickness (ITWT; \%), increase of teat thickness (ITT; $\%$ ), increase of teat wall area (ITWA; \%), increase of teat end area (ITEWA; \%), and increase of teat canal length (ITCL; \%).

Vacuum-Level Variables. The variables related to the variation of vacuum level were recorded using Pulsotest Comfort device (GeaFarm Technologies, Bönen, Germany) set with frequency of sample rate of 166.7 Hz. Every month, 20 vacuum-level measurements within each of the groups were recorded. The measurements were performed in the short milk tubes including the DT in T15020 and T20010 and the machine stripping in TC. The variables recorded were maximum vacuum level $(\mathrm{kPa})$ and minimum vacuum level $(\mathrm{kPa})$. From their values, mean vacuum drop (maximum vacuum level - minimum vacuum level; $\mathrm{kPa}$ ) was calculated.

\section{Statistical Analysis}

Variable SCC was transformed $\left(\log _{10} \mathrm{SCC}\right)$ to achieve normality of distribution (Ali and Shook, 1980). Taking into account the daily records of both pre-experimental and experimental period of MM and milking duration from both milkings, the mean values of these variables on the previous and following week to the sampling days were calculated ( 1 value per animal in the preexperimental period and 1 value per animal per month in the experimental period) as the analyzed variables: daily record MM and daily record milking duration.

To determine the initial characteristics of the 3 groups of animals included in the experiment, a general linear model (Proc GLM; SAS Institute Inc., 2012) was employed on the values of the pre-experimental period of the dependent variables related to (1) efficacy of milking (daily record MM, daily record milking duration, test day milking duration, test day MM, and HSM, from both milkings and milking duration of a row), (2) milk composition (fat, protein, lactose), and (3) teat-end status (ITWT, ITT, ITWA, ITEWA, and 
ITCL) considering each group of animals $(1,2,3)$ as a factor.

The association between the dependent variables related to milking efficiency (daily record MM, daily record milking duration, test day milking duration, test day MM, and HSM, from both milkings), total milk, milk composition (fat, protein, lactose), and $\log 10$ SCC and the treatments applied was studied employing a linear mixed model (Proc GLIMMIX; SAS Institute Inc., 2012). Fixed effects included treatment (3 levels: TC, T15020, and T20010), parity (primiparous and multiparous), month of lactation (4 levels: $2-5$ ), and their respective pre-experimental covariables (values of each variable recorded in the pre-experimental period). In this case, the effects of mammary gland sanitary status (2 levels: healthy and subclinical mastitis), the interaction between treatment and month of lactation and the interaction between treatment and parity were not included in the model, as they were not significant. The respective covariables MM (daily records and sampling days) were considered in the milkings duration analysis (daily records and sampling days).

The association between the dependent variables related to teat-end status (ITWT, ITT, ITWA, ITEWA, and ITCL) and the treatments employed was studied utilizing another linear mixed model (Proc GLIMMIX; SAS Institute Inc., 2012). Fixed effects included treatment and month of lactation. In this case, parity and the values of each variable recorded in the preexperimental period were not included in the model, as they were not significant.

In all models, the animal was considered as a random term and a compound symmetry covariance structure was used to consider repeated measures over time in the same animal. The model using this hierarchical structure provided the best fit for the data when compared with different models considering other covariance and hierarchical structures (as assessed using Bayesian and Akaike information criteria).

A general linear model (Proc GLM; SAS Institute Inc., 2012) was used to study the association of the treatment (TC, T15020, and T20010) with milking duration of a row, considering the month of lactation and treatment as factors. To study the association of the treatment (TC, T15020, and T20010) with the quantity of new cases of mastitis, Chi squared analyses (Proc Freq.; SAS Institute Inc., 2012) were computed.

Finally, a general linear model (Proc GLM; SAS Institute Inc., 2012) was employed to study the association of the treatment (TC, T15020, T20010) with the maximum vacuum level, the minimum vacuum level, and the mean vacuum drop, considering treatment as factor. Month of lactation was not included in the final model, as it was not significant.

\section{RESULTS}

Pre-experimental measures showed that there were no differences among the 3 groups before the study in all the variables tested.

\section{Milking Fraction and Milking Duration}

The analysis of the sampling values showed that the treatment had a significant effect $(P<0.01)$ on MM in the morning milking and on HSM and milking duration in both daily milkings. Nevertheless, the treatment had no effect on MM in the afternoon milking and total milk. Month of lactation, the pre-experimental values, and parity had an effect on each of these variables; thus, minor values were observed in primiparous ewes and as lactation progressed. Conversely, parity had no effect on total milk and milking duration. The interaction between treatment and month of lactation had no effect on any variable.

Daily record MM showed greater values in TC compared with T20010 (differences of $0.11 \mathrm{~kg}, P<0.05$ ). However, there were no differences between T15020 and TC or T20010. Also, no differences were found in the same variable in the afternoon milkings. Similar results were observed in the morning milking of the sampling days. Nevertheless, in the afternoon milking of the sampling days, differences of $0.19 \mathrm{~kg}$ between TC and T15020 and $0.17 \mathrm{~kg}$ between TC and T20010 were found (Table 1).

Regarding HSM, TC showed significant lower values in both daily milkings compared with T15020 and T20010. Differences of $102 \mathrm{~g}$ in the morning milking were observed with regard to both treatments and maximum differences of $80 \mathrm{~g}$ with regard to T15020 in the afternoon milking. Nevertheless, the greater values of HSM in T15020 and T20010 did not involve a decrease in total milk (estimation of total milk synthetized, Table 1).

With respect to milking duration (on sampling days and in daily values), TC showed the greatest values in both milkings (morning and afternoon). The results of milking duration of a row were strongly affected by the treatment employed, which agreed with the values of milking duration. Thus, the use of AVCD entailed a great reduction of the milking duration of a row. Differences in this variable between TC and T15020 were $18 \mathrm{~s}$ in the morning milking and $48 \mathrm{~s}$ in the afternoon milking. Differences in this variable between TC and 
Table 1. Effect of the different treatments used (means $\pm \mathrm{SE}$ ) on variables related to milking fractioning and milking duration in Manchega ewes ${ }^{1}$

\begin{tabular}{lccc}
\hline Variable $^{2}$ & TC & T15020 & T20010 \\
\hline Daily record MM1 (kg) & $0.74 \pm 0.02^{\mathrm{a}}$ & $0.68 \pm 0.02^{\mathrm{ab}}$ & $0.63 \pm 0.02^{\mathrm{b}}$ \\
Daily record MM2 (kg) & $0.50 \pm 0.02$ & $0.51 \pm 0.02$ & $0.49 \pm 0.02$ \\
Test Day MM1 (kg) & $0.72 \pm 0.02^{\mathrm{a}}$ & $0.68 \pm 0.02^{\mathrm{ab}}$ & $0.64 \pm 0.02^{\mathrm{b}}$ \\
Test Day MM2 (kg) & $0.44 \pm 0.02^{\mathrm{a}}$ & $0.25 \pm 0.02^{\mathrm{b}}$ & $0.27 \pm 0.02^{\mathrm{b}}$ \\
HSM1 (g) & $34 \pm 16^{\mathrm{a}}$ & $136 \pm 16^{\mathrm{b}}$ & $136 \pm 16^{\mathrm{b}}$ \\
HSM2 (g) & $32 \pm 8^{\mathrm{a}}$ & $112 \pm 8^{\mathrm{b}}$ & $108 \pm 8^{\mathrm{b}}$ \\
TM (kg) & $1.21 \pm 0.03$ & $1.18 \pm 0.03$ & $1.16 \pm 0.03$ \\
Daily record MD1 (s) & $140 \pm 3^{\mathrm{a}}$ & $121 \pm 3^{\mathrm{b}}$ & $95 \pm 3^{\mathrm{c}}$ \\
Daily record MD2 (s) & $127 \pm 3^{\mathrm{a}}$ & $104 \pm 3^{\mathrm{b}}$ & $82 \pm 3^{\mathrm{c}}$ \\
Test Day MD1 (s) & $138 \pm 3^{\mathrm{a}}$ & $118 \pm 3^{\mathrm{b}}$ & $95 \pm 3^{\mathrm{c}}$ \\
Test Day MD2 (s) & $102 \pm 2^{\mathrm{a}}$ & $81 \pm 2^{\mathrm{b}}$ & $74 \pm 2^{\mathrm{c}}$ \\
RD1 (s) & $230 \pm 5^{\mathrm{a}}$ & $212 \pm 5^{\mathrm{b}}$ & $166 \pm 5^{\mathrm{c}}$ \\
RD2 (s) & $203 \pm 5^{\mathrm{a}}$ & $155 \pm 5^{\mathrm{b}}$ & $125 \pm 5^{\mathrm{c}}$ \\
\hline
\end{tabular}

${ }^{\mathrm{a}-\mathrm{c}}$ Values in the same row with different letters differ at $P<0.01$.

${ }^{1} \mathrm{TC}=$ manual cluster removal; T15020 = automatic cluster removal using a milk flow threshold of $150 \mathrm{~g} / \mathrm{min}$ and a delay time of $20 \mathrm{~s}$; T20010 = automatic cluster removal using a milk flow threshold of $200 \mathrm{~g} / \mathrm{min}$ and a delay time of $10 \mathrm{~s}$. Number of ewes in each group $=36$.

${ }^{2} \mathrm{MM}=$ machine milk; HSM = hand-stripping milk; $\mathrm{TM}=$ total milk extracted; $\mathrm{MD}=$ milking duration; $\mathrm{RD}$ $=$ milking duration of a row (18 ewes per row); 1 after variable means morning milking, 2 means afternoon milking.

T20010 were $64 \mathrm{~s}$ in the morning milking and $78 \mathrm{~s}$ in the afternoon milking (Table 1).

\section{Milk Composition, Mammary Gland Sanitary Status, Teat-End Status, and Vacuum Levels}

Milk composition variables were affected by parity, their pre-experimental values, and month of lactation, but not by the treatment; thus, an increase of their values was observed while lactation advanced and in multiparous ewes. Regarding SCC, no differences between the 3 treatments studied or due to parity were found. The effect of month of lactation involved a general increase in SCC as the lactation advanced (from 56,000 cells $/ \mathrm{mL}$ in the first month to 142,000 cells $/ \mathrm{mL}$ in the last month). Moreover, the quantity of new cases of mastitis during the lactation was very scarce (3 new cases with respect to 36 ewes in each treatment, Table 2), one of them (in T20010) being a clinical mastitis case in the last month of lactation.

Except ITWT, the variables related to the teatend status were significantly lower $(P<0.05)$ when AVCD were used (Table 2). The month of lactation had effect on every variable, except on ITWA, but no tendencies were observed throughout lactation. The treatment applied had an effect on the vacuum levels in the short milk tubes. Despite this, the differences were small in maximum vacuum level (differences of $1.01 \mathrm{kPa}$ between $\mathrm{TC}$ and $\mathrm{T} 15020$, and of $0.90 \mathrm{kPa}$ between T20010 and T15020). The values in the minimum vacuum level were more relevant; differences between TC and the treatments that employed AVCD were significant (maximum differences were up to 7.72 $\mathrm{kPa}$ between T15020 and TC). This latter fact implied that the utilization of TC entails higher values of mean vacuum drop than T20010 and T15020 (differences of 6.74 and $6.68 \mathrm{kPa}$, respectively; Table 2).

\section{DISCUSSION}

The results of $\mathrm{MM}$ in the morning milkings in the sampling days (test day MM1) and those obtained in the previous and in the following weeks to the sampling weeks (daily record MM1) showed similar differences between treatments studied. Conversely, data of the afternoon milkings in the sampling days (test day MM2) showed differences between treatments. This fact did not happen on the regular days (daily record MM2). This situation is explained by the extraction of HSM in the morning milking of the sampling days; thus, part of this HSM would be corresponded with MM of the afternoon milking in days that samplings were not performed (daily record MM2).

The use of AVCD set with the optimal parameters (T15020) in the milking of Manchega ewes achieved amounts of machine milk similar to those obtained with manual cluster removal and machine-stripping. The results obtained when T15020 was used agree with those found in Murciano-Granadina goats by our research group [J. Bueso-Ródenas, G. Romero, M. P. Gascó (Universidad Miguel Hernández), and J. R. Diaz, unpublished data], who found that AVCD set with MF 100 to $150 \mathrm{~g} / \mathrm{min}$ and DT $10 \mathrm{~s}$ were equally effective as manual removal performed by an experienced milker. 
Table 2. Effect of the different treatments used (means \pm SE) on milk composition, sanitary status of the mammary gland, teat end status, and vacuum levels in Manchega ewes ${ }^{1}$

\begin{tabular}{lcccc}
\hline Variable $^{2}$ & TC & T15020 & T20010 & Significance \\
\hline Fat (\%) & $8.50 \pm 0.12$ & $8.47 \pm 0.13$ & $8.40 \pm 0.12$ & NS \\
Protein (\%) & $6.21 \pm 0.05$ & $6.30 \pm 0.05$ & $6.33 \pm 0.04$ & NS \\
Lactose (\%) & $4.60 \pm 0.03$ & $4.57 \pm 0.03$ & $4.59 \pm 0.03$ & NS \\
SCC (× 10 cells $/ \mathrm{mL})$ & $96 \pm 11$ & $92 \pm 11$ & $96 \pm 11$ & NS \\
MASTNC (n) & 3 & 3 & 3 & NS \\
ITWT (\%) & $28.89 \pm 3.46$ & $22.09 \pm 3.57$ & $25.16 \pm 3.49$ & NS \\
ITWA (\%) & $12.32 \pm 1.84^{\mathrm{a}}$ & $1.84 \pm 1.89^{\mathrm{b}}$ & $4.14 \pm 1.85^{\mathrm{b}}$ & $* *$ \\
ITEWA (\%) & $38.99 \pm 4.4^{\mathrm{a}}$ & $17.67 \pm 4.5^{\mathrm{b}}$ & $16.88 \pm 4.5^{\mathrm{b}}$ & $* *$ \\
ITT (\%) & $4.43 \pm 1.08^{\mathrm{a}}$ & $2.01 \pm 1.12^{\mathrm{ab}}$ & $0.01 \pm 1.09^{\mathrm{b}}$ & $* *$ \\
ITCL (\%) & $45.34 \pm 4.00^{\mathrm{a}}$ & $26.49 \pm 4.11^{\mathrm{b}}$ & $23.17 \pm 4.03^{\mathrm{b}}$ & $* *$ \\
MAXVL (kPa) & $36.71 \pm 0.35^{\mathrm{a}}$ & $37.72 \pm 0.36^{\mathrm{b}}$ & $36.62 \pm 0.35^{\mathrm{a}}$ & $*$ \\
MINVL (kPa) & $24.21 \pm 0.73^{\mathrm{a}}$ & $31.93 \pm 0.76^{\mathrm{b}}$ & $30.79 \pm 0.76^{\mathrm{b}}$ & $* *$ \\
VD (kPa) & $12.5 \pm 0.7^{\mathrm{a}}$ & $5.8 \pm 0.7^{\mathrm{b}}$ & $5.8 \pm 0.7^{\mathrm{b}}$ & $* *$ \\
\hline
\end{tabular}

$\overline{\mathrm{a}, \mathrm{b}}$ Values in the same row with different letters differ at $P<0.05\left(^{*}\right)$ or $P<0.01\left({ }^{* *}\right)$.

${ }^{1} \mathrm{TC}=$ manual cluster removal; T15020 = automatic cluster removal using a milk flow threshold of $150 \mathrm{~g} / \mathrm{min}$ and a delay time of $20 \mathrm{~s}$; T20010 = automatic cluster removal using a milk flow threshold of $200 \mathrm{~g} / \mathrm{min}$ and a delay time of $10 \mathrm{~s} ; \mathrm{SL}=$ significant level. Number of ewes in each group $=36$. Number of ewes with healthy udders at the onset of the experiment in each group: $\mathrm{TC}=33$; $\mathrm{T} 15020=33$; $\mathrm{T} 20010=32$.

${ }^{2} \mathrm{SCC}=\operatorname{antilog} 10$ of LSCC; MASTNC $=$ new cases of subclinical mastitis during the experiment; ITWT = percentage variation after milking of teat wall thickness; ITWA = percentage variation after milking of teat wall area; ITEWA = percentage variation after milking of teat end wall area; ITT = percentage variation after milking of teat thickness; ITCL $=$ percentage variation after milking of teat canal length; MAXVL $=$ maximum vacuum level; MINVL = minimum vacuum level; VD = vacuum drop.

As expected, the performance of the machine stripping reduced the amount of HSM in TC. This fact did not involve a reduction in Daily record MM in T15020. In this case, the milk remaining in the udder after automatic cluster removal is extracted in the following milkings. Moreover, this greater amount of HSM did not involve a lower value of total milk, implying that a lesser emptying of the udder did not affect the milk synthesis course by its accumulation, as observed in other works (Wilde and Knight, 1990; Salama et al., 2003). The explanation for these higher values of HSM is found in the udder morphology of this species, where there is a significant quantity of animals whose teats are located above the base of the mammary gland (Labussiére, 1988; Bruckmaier et al., 1997). This character is not related to the productive aptitude of the ewes (Fernandez et al., 1995), thus the solution to this drawback could include the udder morphology as a factor of the selection to improve its adaptation to machine milking, as is currently done in some breeds of ewes (Marie-Etancelin et al., 2005).

The most relevant results in terms of milking efficiency were the differences found in individual milking duration and, especially, in milking duration of a row. The results of milking duration in T15020 and T20010 agree with those found in similar studies carried out in dairy cows (Sagi, 1978; Stewart et al., 2002; Jago et al., 2010). The use of the AVCD set with T15020 would be more efficient than the conventional milking with manual cluster removal, as it obtained a similar amount of extracted milk but took less time. Along the same line, the utilization of AVCD set with MF $200 \mathrm{~g} /$ min and DT $10 \mathrm{~s}$, although it would involve a higher reduction of milking duration and milking duration of a row, would offer values of milk extracted substantially reduced ( $0.11 \mathrm{~kg}$ of milk per ewe) losses that could affect the profitability of the farm.

Regarding teat-end status, the results obtained were similar to those observed by Alejandro et al. (2014) in the same breed in similar conditions. In the current study, the animals milked with manual cluster removal suffered higher teat congestion, which was due to the longer milking duration (Hamann et al., 1994) and bigger risk of the teat cups remaining attached with low milk flows (Mein et al., 2001).

In our long-term study, the values of vacuum drops with TC were higher than those found in T15020 and T20010. This fact can be explained by 2 events that happened in the final phases of the milking. First, the teat lost turgidity and did not fill the liner capacity, allowing air intake (Le Du, 1977); this would not happen with AVCD, as the milking would finish before milk flow stops. Second, machine stripping occurred, which increased the milk flows (Ambord and Bruckmaier, 2010).

The deeper vacuum drops and the higher congestion suffered by the teats of the animals included in TC did not involve changes in the sanitary status of the mammary gland. These results agree with works carried out by Manzur et al. (2012), where similar values 
of the vacuum drops $(3.5-12.4 \mathrm{kPa})$ were not related to changes in this variable. Regarding the congestion of the teat end, it has been observed in Manchega ewes that the application of over-milking (1.5-2 min) during a period of 10 wk did not cause changes in the mammary gland health status (Peris et al., 2003).

The absence of differences in the milk composition between treatments agreed with the results observed when comparing routines with machine stripping and routines without machine stripping (Knight and Gosling, 1995; McKusick et al., 2002). Moreover, this absence of differences between the treatments tested would be concordant to the results for mammary gland sanitary status and the productive level of the animals (Leitner et al., 2004; Cuccuru et al., 2011).

\section{CONCLUSIONS}

In Manchega ewes, the use of AVCD limited the vacuum drops in the short milk tubes and the edema in the teat end after milking and showed similar milk composition and sanitary status of the mammary gland. Moreover, the milking with AVCD set with the optimal parameters (MF $150 \mathrm{~g} / \mathrm{min}$ and DT $20 \mathrm{~s}$ ), was more efficient than manual cluster removal, as it achieved similar amounts of MM reducing milking duration and milking duration of a row. Nevertheless, the use of AVCD set with MF $200 \mathrm{~g} / \mathrm{min}$ and DT 10 involved a significant loss in MM, which could affect the profitability of the farm.

\section{ACKNOWLEDGMENTS}

This study was part of the program of research AGL2009-10695 funded by Ministerio de Ciencia e Innovación (Madrid, Spain). The authors acknowledge Roberto Gallego and Oscar García of Asociación Nacional de Criadores de Ganado Ovino Selecto de Raza Manchega for the supervision of the animal handling and Bonastre Oliete of Centro Regional de Selección y Reproducción Animal for her collaboration in the field work.

\section{REFERENCES}

Alejandro, M., M. Rodríguez, C. Peris, and J. R. Díaz. 2014. Study of ultrasound scanning as method to estimate changes in teat thickness due to machine milking in Manchega ewes. Small Rumin. Res. 119:138-145.

Ali, A. K., and G. E. Shook. 1980. An optimum transformation for somatic cell concentration in milk. J. Dairy Sci. 63:487-490.

Ambord, S., and M. Bruckmaier. 2010. Milk flow dependent vacuum loss in highline milking systems: Effects on milking characteristics and teat tissue condition. J. Dairy Sci. 93:3588-3594.

Bruckmaier, R. M., G. Paul, H. Mayer, and D. Schams. 1997. Machine milking of Ostfriesian and Lacaune dairy sheep: udder anatomy, milk ejection and milk characteristics. J. Dairy Res. 64:163-172.
Bueso-Ródenas, J., G. Romero, R. Arias, A. M. Rodríguez, and J. R. Díaz. 2014b. Effect of the settings of two automatic cluster removers (ACRs) on the milking efficiency of Manchega ewes. Small Rumin. Res. 120:224-230.

Bueso-Ródenas, J., G. Romero, A. Roca, and J. R. Díaz. 2014a. Effect of one automatic cluster remover (ACR) setting on the milking of Murciano-Granadina goats. Livest. Sci. 161:193-200.

Cuccuru, C., M. Meloni, E. Sala, L. Scaccabarozzi, C. Locatelli, P. Moroni, and V. Bronzo. 2011. Effects of intramammary infections on somatic cell score and milk yield in Sarda sheep. N. Z. Vet. J. 59:128-131.

Díaz, J. R., M. Alejandro, and C. Peris. 2013. Use of ultrasound scanning to estimate teat wall thickness in Murciano-Granadina goats. Livest. Sci. 155:114-122.

Edwards, J. P., J. G. Jago, and N. Lopez-Villalobos. 2013. Milking efficiency for grazing dairy cows can be improved by increasing automatic cluster remover thresholds without applying premilking stimulation. J. Dairy Sci. 96:3766-3773.

Fernandez, G., P. Álvarez, F. San Primitivo, and L. F. De la Fuente. 1995. Factors affecting variation of the udder traits of dairy ewes. J. Dairy Sci. 78:842-849.

Hamann, J., C. Burvenich, M. Mayntz, O. Osteras, and W. Haider 1994. Machine-induced changes in the status of the bovine teat with respect to the new infection risk. Int, Dairy Fed. Bull. 297:23-32.

Jago, J. G., J. Burke, and J. H. Williamson. 2010. Effect of automatic cluster remover settings on production, udder health, and milking duration. J. Dairy Sci. 93:2541-2549.

Knight, T. W., and L. S. Gosling. 1995. Effects of milking frequency and machine-stripping on the yield and composition of milk from Poll Dorset ewes. N. Z. J. Agric. Res. 38:123-130.

Labussière, J. 1988. Review of physiological and anatomical factors influencing the milking ability of ewes and the organization of milking. Livest. Sci. 18:253-274.

Le Du, J. 1977. La machine à traite: Incidence des facteurs associés au fonctionnement du manchon. Ann. Med. Vet. 121:309-321.

Leitner, G., M. Chaffer, A. Shamay, F. Shapiro, U. Merin, E. Ezra, A. Saran, and N. Silanikove. 2004. Changes in milk composition as affected by subclinical mastitis in sheep. J. Dairy Sci. 87:46-52.

Leitner, G., M. Chaffer, S. Zamir, T. Mor, A. Glickman, M. Winkler, L. Weisblit, and A. Saran. 2001. Udder disease etiology, milk somatic cell counts and NAGase activity in Israeli Assaf sheep throughout lactation. Small Rumin. Res. 39:107-112.

Magliaro, A. L., and R. S. Kensinger. 2005. Automatic cluster remover setting affects milk yield and machine-on time in dairy cows. J. Dairy Sci. 88:148-153.

Manzur, A., J. R. Díaz, A. Mehdid, N. Fernández, and C. Peris. 2012 Effect of mid-line or low-line milking systems on milking characteristics in goats. J. Dairy Res. 79:375-382.

Marie-Etancelin, C., J. M. Astruc, D. Porte, H. Larroque, and C Robert-Granié. 2005. Multiple-trait genetic parameters and genetic evaluation of udder-type traits in Lacaune dairy ewes. Livest. Sci. 97:211-218.

McKusick, B. C., D. L. Thomas, and Y. M. Berger. 2003. Effect of omission of machine stripping on milk production and parlor throughput in East Friesian dairy ewes. J. Dairy Sci. 86:680-687.

McKusick, B. C., D. L. Thomas, Y. M. Berger, and P. G. Marnet. 2002. Effect of milking interval on alveolar versus cisternal milk accumulation and milk production and composition in dairy ewes. J. Dairy Sci. 85:2197-2206.

Mein, G. A., F. Neijenhuis, W. F. Morgan, D. J. Reinemann, J. E. Hillerton, J. R. Baines, I. Ohnstad, M. D. Rasmussen, L. Timms, J. S. Britt, R. Farnsworth, N. Cook, and T. Hemling. 2001. Evaluation of bovine teat condition in commercial dairy herds: 1 . Noninfectious factors. Pages 374-351 in Proc. 2nd Int. Symp. Mast. Milk Qual. NMC/AABP, Vancouver, Canada. National Mastitis Council Inc., Madison, WI.

Molina, M. P., X. Such, N. Fernández, G. Caja, and A. Torres. 1989 Supresión del repaso manual en el ordeño mecánico de ovejas de raza Manchega. 1. Efecto sobre la producción de leche y el fraccionamiento de la leche en el ordeño. Pages 655-679 in: 4th In- 
ternational Symposium on Machine Milking of Small Ruminants. Kibbutz Shefayim, Tel-Aviv, Israel. Ministry of Agriculture, TelAviv, Israel.

Olechnowicz, J. 2012. The course of machine milking in small ruminants. Chapter 10 in Milk Production - An Up-to-Date Overview of Animal Nutrition, Management and Health. InTech, Rijeka, Croatia.

Peris, C., J. R. Díaz, S. Balasch, M. C. Beltran, M. P. Molina, and N. Fernandez. 2003. Influence of vacuum level and overmilking on udder health and teat thickness changes in dairy ewes. J. Dairy Sci. 86:3891-3898.

Rasmussen, M. D. 1993. Influence of switch level of automatic cluster removers on milking performance and udder health. J. Dairy Res. 60:287-297.

Reid, D., and A. Stewart. 1997. The effects on parlor performance by variations of detacher settings. Pages 101-104 in Proc. 36th Annu. Mtg. Natl. Mastitis Counc., Albuquerque, NM. National Mastitis Council Inc., Madison, WI.

Sagi, R. 1978. Milk flow rate and end of milking detectors. Pages 328 334 in Proc. 17th Annu. Mtg. Natl. Mastitis Counc., Louisville, KY. National Mastitis Council Inc., Madison, WI.

Salama, A. A. K., X. Such, G. Caja, M. Rovai, R. Casals, E. Albanell, M. P. Marín, and A. Martí. 2003. Effects of once versus twice daily milking throughout lactation on milk yield and milk composition in dairy goats. J. Dairy Sci. 86:1673-1680.

SAS Institute Inc. 2012. SAS version 9.2. User's Guide. SAS Institute Inc., Cary, $494 \mathrm{NC}$

Stewart, S., S. Godden, P. Rapnicki, D. Reid, A. Johnson, and S. Eicker. 2002. Effects of automatic cluster remover settings on average milking duration, milk flow, and milk yield. J. Dairy Sci. $85: 818-823$.

Tangorra, F. M., A. Costa, and A. Guidobono-Cavalchini. 2010. Preliminary results of a field study on goats milk yield and lactation persistency as affected by automatic cluster removals. Pages 592598 in Proc. Int. Conf. SHWA2010: Work Safety and Risk Prevention in Agro-Food and Forest Systems, Ragusa, Italy. Universita degli Studi di Catania, Catania, Italy.

Tangorra, F. M., M. Zaninelli, and L. Mercandino. 2007. Effect of automatic cluster removal on parlor performance and unit cost of milking in dairy goats. Pages 639-646 in Proc. XXXII CIOSTACIGR: Advances in labor and machinery management for a profitable agriculture and forestry, Nitra, Slovakia. Solvak University of Agriculture, Nitra, Slovakia.

Wilde, C. J., and C. H. Knight. 1990. Milk yield and mammary function in goats during and after once-daily milking. J. Dairy Res. $57: 441-447$. 